\title{
Commercialised Sexual Exploitation of Children, Adolescents and Women: Health and Social Structure in Bangladesh
}

\author{
Christopher Bagley ${ }^{1}$, Sadia Kadri², Afroze Shahnaz', Padam Simkhada ${ }^{1}$, Kathleen King3 \\ ${ }^{1}$ Public Health Institute, Liverpool John Moores University, Liverpool, UK \\ ${ }^{2}$ Independent Researcher, Manchester, UK \\ ${ }^{3}$ Independent Researcher, Edmonton, Canada \\ Email: chrisbagley2@gmail.com
}

How to cite this paper: Bagley, C., Kadri, S., Shahnaz, A., Simkhada, P., \& King, K. (2017). Commercialised Sexual Exploitation of Children, Adolescents and Women: Health and Social Structure in Bangladesh. Advances in Applied Sociology, 7, 137-150. https://doi.org/10.4236/aasoci.2017.74008

Received: February 27, 2017

Accepted: March 28, 2017

Published: March 31, 2017

Copyright $\odot 2017$ by authors and Scientific Research Publishing Inc. This work is licensed under the Creative Commons Attribution International License (CC BY 4.0).

http://creativecommons.org/licenses/by/4.0/

\begin{abstract}
Background: This research is based on our argument that the commercial sexual exploitation of women and children (CSEWC) often includes a variety of abuses, sexual, physical, emotional, and economic. In Bangladesh, "Sex work" is a major industry, and about two percent of girls and women in the population aged 12 to 30 are subject to the status of CSEWC. Methods: From a review of literature and from ethnographic field work, we present an analysis of the sexual abuse of children, girls and women engaged in "sex work" in Bangladeshi brothels, addressing as well issues of STIs and HIV infection, in men who use CSEWC. Findings: Adolescents who are forced to become CSEWC suffer multiple forms of abuse, which may be life-threatening. Bangladeshi men of all ages and classes use CSEWC. Rates of HIV/AIDS remain relatively low (but may infect 5 percent in CSEWC). However, STIs (sexually transmitted infections) affect 50 percent of CSEWC, and at least 15 percent of men who use them. There is some evidence that men's widespread use of CSEWC spreads STIs to their wives, so that rates in women in the general population are relatively high. The CSEWC themselves suffer numerous physical and sexual abuses including bondage and trafficking to India and the Middle East. Police and local officials are involved in the toleration of this abuse, and about a third of money paid by men for sexual services passes to corrupt officials. Conclusions: We advocate support for the growing movement of adult women who campaign against the use of CSEWC, as a means of ending at least the exploitation of children and adolescents. We advocate also the development and evaluation of programmes of preventive education for high school students, as well as the reiteration of the norms of an Islamic culture which should end the sexual abuse of women and children. We also advocate the introduction of a basic income which would give women choices,
\end{abstract}


enabling them to escape the life of CSEWC. Our final recommendation is for a major programme of research and evaluation of programme innovation which will describe the extent of, and ways of preventing, the commercial sexual exploitation of girls and women in Bangladesh.

\section{Keywords}

Bangladesh, Women's Rights, Prostitution, Brothels, Child Sexual Abuse, STIs, Islam

\section{Introduction}

Farley et al. (2015) divided those who do research on prostituted women into two general camps: those who view "sex work" as labour, which implies some degree of voluntary entry; and those who see such activity as part of the broader spectrum of "sexual exploitation", of children, adolescents and women, a status in which the individuals involved have few choices, and suffer great harm, which is often life-threatening in nature. We belong, firmly, to the latter group of scholars and activists. The nature of "sex work" (or CSEWC: commercialised sexual exploitation of women and children, as we prefer to call it, King, 2016) varies in different world cultures, reflecting different traditions, moral values, and legal systems.

One important variable is the role of "sex tourists" who visit countries such as Thailand and The Philippines (Jeffrey, 2003; Law, 2003; Urada et al., 2014; Bagley et al., 2017). In other countries of Asia, such as Pakistan, India, Nepal and Bangladesh the men who access sexually exploited girls and women, are almost entirely from local cultures (Emmanuel et al., 2013; Khairin et al. 2005; Sarkhar et al., 2008; Simkhada \& Bagley, 2008; Vanderpitte et al., 2006).

Bangladesh provides an extraordinary case study of commercialised sexual exploitation (CSE), which is enforced through bonds of poverty, and sanctioned by a corrupt legal and administrative system. This country is one of the world's poorest, with an average income of US $\$ 1440$ per annum. However, national income is unevenly distributed, and 13 percent of Bangladeshi adults have an income that is less than US $\$ 2$ per day ( $\$ 730$ per annum) (Misha \& Sulaiman, 2016). Most girls do not complete primary education, and 18 percent of women marry before the age of 15 , usually to men at least a decade older (Rashid, 2006).

There has been no comprehensive study of Commercially Sexually Exploited Women and Children (CSEWC) in Bangladesh which form the basis of systematic public health proposals. There are some high quality journalistic accounts, and some good quality ethnographic studies of children, of whom the sexually exploited form a sub-group (Blanchet, 2001; Shamim, 2010), and some good quality work on male sexual behaviours, which we review below. But an up-todate comprehensive overview, which studies not only the brothel-villages, but also red-light areas, and sexually-exploited street children is lacking. Therefore 
this review and preliminary ethnographic study must be regarded as the first step in mounting a more comprehensive enquiry.

\section{The Brothels of Bangladesh}

Bangladesh is an overtly Muslim society (a religion which encompasses, in the conduct of everyday life, strict rules forbidding "fornication"): nevertheless "brothels"-entire villages clustered within urban centres-are legally tolerated, and widely used by men. The Guardian newspaper of London has taken a special interest in these "sex villages", and the feature articles and filmed reports by its correspondents are worthy of consultation by those who seek ethnographic insights into life in these villages, and the men who frequent them ${ }^{1}$.

"Prostitution" (legally defined as penetrative sexual relations between a man and a woman aged 18 or over, in which money has been paid for this sexual access) is generally legal in Bangladesh, but statutes specify fines, and periods of imprisonment for sexually using, or trafficking for sexual purposes, those aged less than 18, and for being an intermediate person in sexual transactions involving persons of any age. We have been unable to locate any reports or information concerning prosecutions in this regard, however. "Operating or working in a brothel" apparently has an ambiguous legal status, which police and local officials exploit, allowing women to continue in sex work only if they pay "fines" (i.e. bribes, to corrupt police and officials) (SWN \& SWASA, 2016).

Police also have the power to arrest any woman on arbitrary grounds, as "a public nuisance", a strategy which ensures that they can pocket bribes from the sex worker, or from the person who "owns" her, in this form of bondage or slavery. To use a sex worker, the customer will pay around US\$2 (two dollars). A third of this will go to corrupt officials, a third to the "owner" of the sex worker, and a third (about 67 cents) to the worker herself: unless she has been sold by her family or by kidnappers, to the brothel, in which case the bonded or enslaved individual (almost always a child or adolescent) will receive nothing (Blanchet, 2001; Shamim, 2010).

Younger CSE people are in greater demand, and may have to service up to 20 males a day. Shamim (2010) who studied these brothel villages, estimated that more than 40 percent of the CSEWC (commercially sexually exploited women and children) were aged 13-17. By the time, she is 30 , a woman is no longer "attractive", so she relies for her meagre existence on the earnings of her younger sisters. Some too will become "managers", a desperate survival strategy in the perpetuation of this commercial sexual exploitation ${ }^{2}$.

Our key informants, who gave detailed information concerning daily life in the Bangladesh brothels were ten women, aged more than thirty, who had left sex work in order to organise collectives of women who campaign for better treatment of those who are forced to perform CSE roles. We drew research in-

${ }^{1}$ See the articles and short films which are available online from www.theguardian.com in the issues of: April 5, 2010; March 14, 2014; November 2, 2016; May 17, 2017.

${ }^{2}$ We draw a parallel here with women who act as agents in female genital mutilation, following the myths imposed by a male dominated culture (Ruiz et al., 2017). 
formants as well from NGOs working in the brothel-villages (Eva et al., 2007; SWT \& SWASA, 2016). Most of the male "clients" are Bangladeshi, with a few Indian migrant workers (truck drivers, bargemen). Bangladesh is not a country which Western sex tourists visit.

The government, at the ministerial level, condemns such trafficking and points to the six "rescue centres" across Bangladesh ${ }^{3}$. These centres take in juveniles, but the numbers who are "rescued" is small, relative to the total number of juveniles coerced into sex work (Shamim, 2010; Zareen, 2014). Apparently, food in these rescue centres is poor, and we were told of occasions in which children were enticed back to the brothels on the promise of better food. One factor hampering the reintegration of rescued children is the continued stigma against CSEWC of any age. Paradoxically, significant numbers of men who use "sex workers", at the same time despise the girls and women whom they exploit (Corraya, 2015). Perpetuating this stigma is part of the process which ensures that little official action is taken on behalf of the vulnerable population of CSEWC.

Bangladesh is unique in being a Muslim majority (89\%) country, in which institutionalised sexual exploitation is a visible, public institution. In Bangladeshi cities, there are 20 brothel-villages containing between 800 and 1,600 exploited women and children, and their dependents, living in one-storey shanty dwellings. Families of women, from grandmother to grandchild, live in these villagesthe children usually being conceived through commercial sexual exploitation, or by their controllers.

In perpetuation of this exploitation, the women who bear children in the brothels are rarely married, and their children are stigmatised from birth. Many of the female children are inducted into sexual exploitation at around the age of 12, while younger male children may be sold to international traffickers ${ }^{4}$. Tragically, this may be the only way in which a woman can earn enough capital to escape from the slavery of the brothel (Blanchet, 2001). Poignant interviews with the young children who had not yet become "sex workers", are presented in the film made by Silverman and Tait (2016). Although others in the publications and media we review, refer to these children as "sex workers", we hesitate to dignify what is a form of slavery with the word "work".

In addition to these brothel-villages, sectors of cities include "red-light" streets and tenement areas, each housing hundreds of women who are commercially sexually exploited sex "workers". The total number of these areas is unknown, but they are widespread. In addition, in several areas of cities there are low-rent "hotels", where the "customer" will pay a somewhat higher fee than in the brothel (Haseen et al., 2012). There are also an unknown number of women who

${ }^{3}$ The reader who is fluent in Bangla, may gain a sense of Ministerial views from several YouTube films, for example: A Documentary of Prostitution Area in Bangladesh: The Documentary Channel. Posted to YouTube on May 10, 2016. https://www.youtube.com/watch?v=gMiObyyoNZY There are several videos, in Bangla, on YouTube on sex work in Bangladesh which provide details of the views of officials, NGOs, and of the women themselves.

${ }^{4}$ The fate of these male children is unknown. Reviews of research have not located any relevant studies (Joffres et al., 2008). 
are "street prostitutes" (Rahman et al., 2000). In the brothel-villages children are born, become objects of sexual exploitation early in life, and they will also be likely to die in the brothel, often at a young age. An organisation of sex workers has been campaigning, so far without success, for the right to bury their dead within the confines of these brothel-villages (SWN \& SWASA, 2016). It is, to us, bizarre, that even after death these sexually exploited women are still denied basic rights.

Brothel managers now frequently require younger teenagers (aged 12 to 17) to take the steroid drug Oradexon (or Dexamethasone), a hydrocortisone medication (also used for fattening cattle, being low cost when purchased in bulk) one of whose side effects causes plumpness of body, so that a 12 -year-old can be passed off as an older or more "attractive" girl, also avoiding official displeasure at the exploitation of obvious children. It appears too that a plump prepubertal child is more attractive to the male who exploits her.

This drug also causes hyperglycaemia, delayed menstruation, hormonal dysfunction, diabetes type 2, raised blood pressure, weakened immune system (with emergence of latent diseases such as TB), kidney disease, and reproductive disorders (low birth weight or malformations in infants born to those taking the drug). Girls may be forced to take this drug for several years, with unknown effects on their long-term health, but early mortality seems a distinct possibility. How this drug may affect the acquisition and physical response to STIs is unknown.

\section{Men, Women and STIs (Sexually Transmitted Infections)}

The feminist researcher Elizabeth Pisani (2008) has raised an angry voice against the "AIDS bureaucracy", the volume of medical researchers whose growing interest in sex workers is funded by granting agencies fearsome of the possibility that women in sex work may be infecting "ordinary" men with HIV/AIDS. Surprisingly, several studies have shown the rate of HIV disease to be relatively low in Bangladeshi CSEWC (national rate $0.15 \%$ in 2014), although rates of Sexually Transmitted Infections (STIs) (chlamydia, syphilis, gonorrhoea and other infections) exceed 50 percent in CSEWC (Azim et al, 2008; Baral et al., 2012; Eva et al., 2007; Hosein \& Chatterjee, 2007; Hossain et al., 2011; Islam \& Congrove, 2008; Khairin et al., 2005; Mondal et al., 2008; Nessa et al., 2008; Rahman et al., 2000; Uddin et al., 2014).

HIV rates are elevated in injecting drug users (mostly males) who share needles (Azim et al., 2008). AIDS/HIV is not, in essence, a sexually transmitted disease, but is mainly transferred through blood maintained at body temperature. Since all Muslim men have been circumcised (a known factor in reducing the harbouring of viral and bacterial infections-World Bank, 2015; Collins et al., 2015). Muslim men may also (for religious reasons) avoid anal intercourse, in which membrane injury is common (allowing blood-to-blood infections). The transmission of HIV in "normal" vaginal sex may be low, even without the use of condoms. This could account for the relatively low rate of HIV/AIDS in 
Bangladesh, which is less than 0.2 percent (Khairin et al., 2005). However, the lifetime prevalence of HIV/AIDS in CSEWC may be in excess of five percent-a lower proportion than in CSEWC in India (Pruss-Ustin et al., 2013). Men and women infected with HIV rarely report the infection at an early stage, and when symptoms mean that hospitalisation is inevitable, a fifth will die within six months, the most common cause being TB as a secondary infection (Shahrin et al., 2014). Commenting on the low rate of ant-retroviral drug medication in these patients (a factor associated with better prognosis) these authors advocate comprehensive programmes of sexual health screening for all of those thought to be at risk. The potential exists for a rapid increase in rates of HIV, without such screening programmes.

Epidemiological research suggests that rates of STIs (other than HIV) are high in Bangladesh, not only in CSEWC, but also in women in the general population (Hawke et al., Khairin et al., 2005; 1999; Bogaerts et al., 2001; Rashid, 2006; Baral et al., 2012; Nessa et al., 2008). This implies that the use of commercially sexually exploited women and children has become to some degree normalised among sectors of Bangladeshi men, both married and unmarried, who pass infections on to their present and future wives.

Rob \& Mutahara (2000) in a study of 2,600 Bangladeshi adolescents found that five percent were sexually experienced (15 percent prior to the age of 16), usually with CSEWC. A unique study from Bangladesh (and indeed, a rare kind of study in the world literature on STIs) comes from Haseen et al. (2012) 5 . These researchers asked 1,013 young men (aged 15 to 25, mean 21.1 years) to provide blood and urine samples, and to complete a short questionnaire when they visited "hotel brothels" in Dhaka, Bangladesh. A quarter of these males were aged 18 or less, and of the whole group $46 \%$ had their first sex in such a hotel, usually before the age of 21 .

Of the young men studied 15 percent were married. Most held office or service sector jobs, a half having completed (or were still attending) high school: $52 \%$ had "good" knowledge of how sexually transmitted diseases were transmitted, and most of this group used condoms. Nevertheless, 37 percent never used condoms. 50 percent used CSEWC at least once a month, and 25 percent did so weekly. Almost all of this latter group used condoms. In the whole sample 15 percent tested positive for one or more of: gonorrhoea, syphilis, genital herpes, or another type of STI. One phenomenon noted were the reports of young men ( $9 \%$ of sample) joining together (probably for financial reasons) in a group, having serial sexual relations with one woman: in such situations, condom use was atypical ${ }^{6}$.

\footnotetext{
${ }^{5}$ Note the valuable study of Qudus (2015) of the sexual histories of men living in slum areas of Pakistan, zones of extreme poverty. According to his informants, $80 \%$ of men said that they had engaged in completed intercourse before marriage, the majority with CSEWC.

${ }^{6}$ There is an extensive literature on "fake condoms", but nothing we can locate in literature or interviews on their use in Bangladesh. When the price of a good quality condom is around US50 cents, and the fee for sex is $\$ 3$ or less, there may be an incentive for brothel managers to give CSEWC cheap (and fragile) alternatives, basically a rubber band with plastic attached.
} 


\section{Moral and Religious Dimensions of Bangladeshi Culture}

Haseen et al. (2012) make a worthwhile proposal: in addressing CSEWC, a good place to start is the education of high school boys. We would add that not only should such education address the "dangers" of such sex, but should also address the rights of women not to be sexually exploited, and the teachings of Islam forbidding such behaviours. Of course, issues of consent, equality and respect for women are contained in the religious values of all world cultures, and are usually reflected in legal statutes. The issue is one of value change for all world cultures, and normative practices with regard to the dignity and equality of women.

We must ask why in predominantly Muslim societies (such as Bangladesh and Pakistan) Islamic norms concerning sexual purity and sexual expression are so frequently ignored ${ }^{7}$. Bradley (2010), Gohir (2010) and Qudus (2015) in surveying the Islamic world, point to Middle Eastern countries as well as Pakistan, Bangladesh and Afghanistan as countries where child marriages are tolerated, commercialised sexual exploitation is common, and daughters may be prostituted by their fathers through the institution of "temporary marriage (mut'ah)" Child marriage is sometimes used in Bangladesh as a means of acquiring a girl who can then be sold to a brothel, for two or three years. During this time, the girl receives no income from her enforced work, since she is "paying off her debt" to the man who exploits her, and regards himself as her "owner".

Several informants also gave accounts of the trafficking of Bangladeshi girls into brothels in India and further afield, often with the false promise of marriage or employment. It is clear from the literature surveyed, and from our informants, that child bondage, trafficking, violence and rape are common in the brothels of Bangladesh, and also for the Bangladeshi girls trafficked to India and elsewhere for commercially exploited sex work (Hengartner et al., 2015; Hudy, 2006; ILO, 1998; UNODC, 2009).

Our informants gave vivid accounts of recent cases of such child slavery, and trafficking of girls into brothels, and the violence imposed on them to ensure sexual conformity. Clark (2015) writes of a world which has ignored the plight of Bangladeshi sex workers, focussing more frequently on the world of sex tourism in Thailand and The Philippines, and the supposed threat of HIV infections to the white men who visit as sex tourists. But there are now welcome signs in Bangladesh and elsewhere of women becoming more militant and organised in their struggle to achieve "better" conditions in commercialised sexual exploitation (SWN \& SWASA, 2016).

Our ethnographic work has identified an interesting phenomenon, of girls from middle class families who spurning arranged marriages, now give mutual support as independent "sex workers," in higher income apartment blocks. These

\footnotetext{
${ }^{7} \mathrm{~A}$ statistical analysis of 32 countries (not including Bangladesh or Pakistan) found that Muslims were the least likely of any religious or cultural group to have engaged in premarital sex (Adamczyk \& Hayes, 2012).

${ }^{8}$ Three of the authors of this paper are Muslims, and wish to uphold and assert the traditional purity and gentle and respectful caring of others, including marital partners, inherent in personal and sexual relationships within Islam.
} 
women include several college students, and graduates. This is an interesting form of a feminist collective which rejects the sexism inherent in men's approach to women in Bangladesh. Lysistrata-like ${ }^{9}$, these women deny men sexual access, unless they pay for it (and also behave themselves in terms of their sexual manners). This development is paralleled by interesting movements both within the brothel villages, and in the wider society, by older women organising collectively for better treatment, a fairer reward for their exploitation, and for a heightened respect for the service they perform (Alam et al., 2013; Eva et al., 2007; Jenkins et al., 2002; Khan, 2013; Pisani, 2008; Salim, 2004). But our fieldwork suggests that this beginning feminist movement has an uphill task (Hosain \& Chaterjee, 2005; Hossain et al., 2014; Kammal et al., 2015; Katz et al., 2015; Sultana, 2015).

The case for an Islamic feminism in Bangladesh has been eloquently argued by Hashmi (2000) in her book Women and Islam in Bangladesh: Beyond Subjection and Tyranny. She begins her book with a quote from The Qur'an: "And for women are rights over men similar to those of men over women." (2:228) She ends her study of Bangladeshi women with the gloomy conclusion: “... patriarchy has been the main stumbling-block towards the empowerment of Bangladeshi women. The marriage of convenience between patriarchy and popular Islam has aggravated the situation." (p. 209).

Just how profound this problem remains comes from epidemiological data from longitudinal and large scale health studies of women in rural Bangladesh (Ahmed et al., 2004; Nahar et al. 2015). This research shows that adolescent females aged 15 to 19, have the highest recorded rate of suicide (more than 15 per $100,000)$ amongst women, compared with virtually every other world country, matched only by that in some districts of India and Sri Lanka (Jordans et al., 2014). The very high rate of completed suicide in adolescent girls in rural Bangladesh is paralleled by their very high rate of death caused by external violence. Ahmed et al. 2004) observed that: "Oppression, physical and mental abuse by husbands and relatives often preceded suicides and homicides. The disadvantaged position of women in Bangladesh society is the key underlying social cause of the violence... in order for the violence against women to decrease, improvement in the social position of women is essential.” (p. 317)

Child marriage (prior to age 15) is common, and girls are "given" to men who are in effect buying them from their impoverished families. Significant numbers of these adolescents are not merely physically and sexually abused by local men: some are shipped to cities to be sold, as bonded workers in Bangladeshi brothels. These brothels recreate the oppressions of village life. We have no systematic data on completed suicide in girls who experience brothel life: but from accounts given by informants, it is not a rare occurrence.

\section{Conclusion and Recommendations}

The ending of child and adolescent sexual exploitation in the Bangladeshi brothels must be a major priority. The rise of militant Islam in Bangladesh may not

${ }^{9}$ Lysistrata is the title of a play by Aristophanes in ancient Greece, where women denied sexual access to men unless they ended an internecine war with a neighbouring state. 
be helpful in this regard: it has, for example, resulted in the burning down of a "red-light" tenement, endangering the lives and impoverishing further, hundreds of girls and women. We note too, with dismay, the actions of a mob in tearing down the structure of one of the brothel villages, and beating and injuring the women there (SWN \& SWASA, 2016). We were unable to get any sense from media and government that there is any official impetus to end this exploitation (Corraya, 2015).

Our final conclusion from this overview of commercially exploited "sex work" in Bangladesh must be one of pessimism. The United Nations Office on Drugs and Crime (2009) as well as various media are well aware of the problems of children and adolescents who are treated as sex slaves. Yet we can find no evidence of progress in ending their exploitation, at any official level.

Our argument is that all of sex work involving minors is a form of slavery, and its continuation can no more be justified than could the slavery of Africans by Europeans in North America. Unfortunately, there are and may always be males who will pay for sexual access to children and women, with no consideration of their rights, welfare or consent. Commodification and subjugation of women infects many sectors of society: commercialised sexual exploitation is yet another example.

The institutionalisation of sexual exploitation of women and children both creates and reinforces the general value that women are creatures who may be violated in brothels, controlled and abused outside of brothels and red-light zones of cultures east and west, and abused in society at large (Bagley, 1997; Bagley \& King, 2003). We must acknowledge that modern sexual slavery is consumer-driven and dependent on inequalities of gender, ethnicity, and social class (Farley \& Kelly, 2008).

The sexual abuse of children, adolescents and women is built into the general ethos of male hegemony in the culture of many countries (Bagley \& Simkhada, 2012; Bagley et al., 2017). Extreme poverty puts both girls and women at extreme risk, and may also be a driver which unleashes the atavism which lurks in the male psyche. World poverty, and its ending, must be a major goal; as well as the enhancement and the growth of both traditional and new values (religious and secular) on the rights and dignity of women (Hashmi, 2000; Salim, 2004).

One viable solution which we advocate is the introduction of a "Citizen's Income" available as a basic right to all. Experimental work in India (Davala et al., 2015; Safi, 2017) has shown that guaranteeing each citizen a basic wage (in the Indian context of about US\$80 a year, and half that sum for all children), decreases malnutrition and increases productivity and school attendance, and for women in particular allows them options of delaying marriage, choosing educational pathways and careers, and increasing choices on when and if to have children. The economics of the citizen's basic income have been extensively discussed by economists and political scientists (Davala et al, 2015; Jameson, 2016; Standing, 2011; Torry, 2015) and it would certainly fit well with a free market economy. 
But of course, ending the commercialized sexual abuse of women and children involves much more than economic issues: fundamental value changes concerning the status of girls and women are necessary in all countries, at whatever stage of economic development.

Our final recommendation, based on this brief literature review and insights gained from ethnography, is that because of the commercial sexual exploitation of girls and women in Bangladesh and the devastation it causes in their lives; and the added problem of widespread prevalence of STIs, and the potential hazard of HIV infections, a major programme of research and surveillance must be initiated. This research would not merely describe the exact extent of the problems in public health terms: it would evaluate programmes of education for healthy sexuality for school students, and would initiate experimental programmes of social, income and health care support which will enable children and adolescents to escape the degraded roles of commercial sexual exploitation.

\section{Ethical Certification}

This work was carried out using an Ethics Certificate issued by the University of Southampton in 2002 for a generic project examining "sex work" in several Asian countries. Specific conditions were that no sex worker should be directly interviewed, unless the researchers had a viable plan for "rescuing" that individual from sex work. In the research reported above, interviews were confined to workers in NGOs (Non-Governmental Organisations) who were active on behalf of sex workers; and members of a Woman's Collective of former sex-workers, campaigning for better conditions for adult sex workers, and the ending of the sexual exploitation of children and adolescents.

\section{Authors' Contributions}

PS initiated this research, assisted by $\mathrm{CB}$. The text of the article was drafted by $\mathrm{CB}$, using a conceptual framework established by KK. All of the authors critiqued the first and subsequent drafts. SK and AS engaged in field work and literature review relating to Bangladesh.

\section{References}

Ahmed, M., van Ginneken, J., Razzaque, A., \& Alam, L. (2004). Violent Deaths among Women of Reproductive Age in Rural Bangladesh. Social Science and Medicine, 59, 311-319. https://doi.org/10.1016/j.socscimed.2004.01.020

Alam, N., Chowdhury, Mridha, M. et al. (2013). Factors Associated with Condom Use Negotiation by Female Sex Workers in Bangladesh. Journal for the Study of Aids, 24, 813-821.

Azim, T. et al. (2008). Bangladesh Moves from Being a Low-Prevalence Nation for HIV to One with a Concentrated Epidemic in Injecting Drug Users. International Journal of Sexually Transmitted Diseases and Aids, 19, 322-332. https://doi.org/10.1258/ijsa.2007.007269

Bagley, C. (1997). Children, Sex and Social Policy: Humanistic Solutions for Problems of Child Sexual Abuse. Aldershot: Ashgate. 
Bagley, C., \& King, K. (2003). Child Sexual Abuse: The Search for Healing. London: Routledge-Taylor \& Francis.

Bagley, C., \& Simkhada, P. (2012). Challenges for Inclusion: Sexual Exploitation and Trafficking of Girls and Women in Canada, Britain, India, Nepal and The Philippines. The Social Engineer, 4, 20-39.

Bagley, C., Madrid, S., Simkhada, P., \& King, K. (2017). Adolescent Girls Growing beyond Commercialised Sexual Exploitation: Case Study from the Philippines of Voluntary Action for Income Support. Submitted for Publication, under Review.

Baral, C., Beyrer, C., Muessig, K. et al. (2012). Burden of HIV among Female Sex Workers in Low-Income and Middle-Income Countries: A Systematic Review and Meta-Analysis. Lancet Infectious Diseases, 12, 538-549. https://doi.org/10.1016/S1473-3099(12)70066-X

Blanchet, T. (2001). Lost Innocence, Stolen Childhoods. Dhaka: University of Bangladesh Press.

Bogaerts, J., Ahmed, J., Akhter et al. (2001). Sexually Transmitted Infections among Married Women in Dhaka, Bangladesh. Sexually Transmitted Infections, 77, 114-119. https://doi.org/10.1136/sti.77.2.114

Bradley, J. (2010). Behind the Veil of Vice: The Business and Culture of Sex in the Middle East. New York, NY: Palgrave-Macmillan.

Clark, J. (2015). Editorial: Bangladesh's Ignored Sex Workers. British Medical Journal, 350, h3470.

Collins, C. et al. (2015). The Art of HIV Elimination: Past and Present Science. Journal of Aids and Clinical Research, 6, 525.

Corraya, S. (2015). Mapping Missing, Kidnapped and Trafficked Children and Women: Bangladeshi Perspective. www.AsiaNews.it

Davala, S., Jhabuala, R., Kapoor, M., \& Standing, G. (2015). Basic Income: A Transformation Policy for India. London: Bloomsbury Academic.

Emmanuel, F., Thompson, L., Athar, V., \& Five Others (2013). The Organisation, Operational Dynamics and Structure of Female Sex Work in Pakistan. Sexually Transmitted Infections, 89, 29-33. https://doi.org/10.1136/sextrans-2013-051062

Eva, N., Munakata, T., \& Onuoha, F. (2007). Demographic Correlates of Constant Condom Use among Workers in Tangail, Dhaka, Bangladesh. Adolescence, 42, 795-804.

Farley, M., \& Kelly, V. (2008). Prostitution: A Critical Review of the Medical and Social Sciences Literature. Women and Criminal Justice, 11, 29-64.

https://doi.org/10.1300/J012v11n04_04

Farley, M., Golding, J., Matthews, E., Malamuth, N., \& Jarrett, L. (2015). Comparing Sex Buyer with Men Who Do Not Buy Sex: New Data on Prostitution and Trafficking. Journal of Interpersonal Violence, 11, 1-25. https://doi.org/10.1177/0886260515600874

Gohir, S. (2010). The Hypocrisy of Child Abuse in Many Muslim Countries. The Guardian. www.theguardian.com

Haseen, F. et al. (2012). Sexually Transmitted Infections and Sexual Behaviour among Youth Clients of Hotel-Based Female Sex Workers in Dhaka, Bangladesh. International Journal of STD and AIDS, 23, 553-559. https://doi.org/10.1258/ijsa.2012.011373

Hashmi, T. (2000). Women and Islam in Bangladesh: Beyond Subjection and Tyranny. Basingstoke: Palgrave MacMillan. https://doi.org/10.1057/9780333993873

Hawke, S., Morison, L., Foster, S. et al. (1999). Reproductive Tract Infection in Low-Income, Low-Prevalence Situations: Assessment of Syndromic Management in Matlab, 
Bangladesh. The Lancet, 354, 1776-1786.

Hengartner, M., Islam, M., Hakes, H., \& Rossler, W. (2015). Mental Health and Functioning of Female Sex Workers in Chittagong, Bangladesh. Frontiers in Psychiatry, 6, 176-181. https://doi.org/10.3389/fpsyt.2015.00176

Hosain, G., \& Chatterjee, N. (2005). Beliefs, Sexual Behaviours and Preventive Practices with Respect to HIV/AIDS among Commercial Sex Workers. Public Health, 119, 371381.

Hossain, M., Marci, K., Sidik, S., Shahar, \& Islam, R. (2014). Knowledge and Awareness about STDs among Women in Bangladesh. BMC Public Health, 14, 774-778. https://doi.org/10.1186/1471-2458-14-775

Hudy, S. (2006). Sex Trafficking in South Asia. International Journal of Gynaecology and Obstetrics, 94, 374-381.

ILO (1998). Sex and Trafficking in South East Asia. Geneva: The International Labor Organisation.

Islam, M., \& Conigrave, K. (2008). HIV and Sexual Risk Behaviors among Recognized High-Risk Groups in Bangladesh: Need for a Comprehensive Prevention Program. International Journal of Infectious Diseases, 12, 363-370.

Jameson, R. (2016). The Case for a Basic Income. London: IMOS. www.IMOS.org.uk

Jeffrey, L. (2003). Sex and Borders: Gender, National Identity, and Prostitution Policy in Thailand. Vancouver: University of British Columbia Press.

Jenkins, C., \& Rahman, H. (2002). Rapidly Changing Conditions in the Brothels of Bangladesh: Impact on HIV/STDs. Aids Education and Prevention, 14, 97-106. https://doi.org/10.1521/aeap.14.4.97.23882

Joffres, C. et al. (2008). Sexual Slavery without Borders: Trafficking for Commercial Sexual Exploitation in India. International Journal of Equity and Health, 7, 22. https://doi.org/10.1186/1475-9276-7-22

Jordans, M. et al. (2014). Suicide in South Asia: A Scoping Review. BMJ Psychiatry, 14, 358.

Kamal S., Hassan, C., \& Salikon, R. (2015) Safer Sex Negotiation and Its Association with Condom Use among Clients of Female Sex Workers in Bangladesh. Asia Pacific Journal of Public Health, 27, 410-422. https://doi.org/10.1177/1010539513510554

Katz, K., McDowell, M., Green, M. et al. (2015). Understanding the Broader Sexual and Reproductive Health Needs of Female Sex Workers in Dhaka, Bangladesh. International Perspectives on Sexual and Reproductive Health, 41, 182-190.

https://doi.org/10.1363/intsexrephea.41.4.0182

Khairin, N., Shama, W., Aadil, B. et al. (2005). Sexually Transmitted Infections among Brothel-Based Sex Workers in Bangladesh. Sexually Transmitted Diseases, 32, 13-19.

Khan, M. (2013). Reducing Harassment of Female Sex Workers (FSWS) in Low Income Settings: Tripartite Approach in Bangladesh. Sexually Transmitted Infections, 89, 329. https://doi.org/10.1136/sextrans-2013-051184.1029

King, K. (2016). From Personal to Political: My Journey through Sexual Exploitation. Edmonton: Sexual Exploitation Working Group.

Law, L. (2003). Sex Work in Southeast Asia: The Place of Desire in a Time of Aids. New York, NY: Routledge-Taylor \& Francis.

Misha, E., \& Sulaiman, M. (2016). Bangladesh Priorities: Poverty. Copenhagen: Copenhagen Consensus Center.

Mondal, N., Hossain, K., Islam, R., \& Mian, A. (2008). Sexual Behavior and Sexually Transmitted Diseases in Female Sex Workers in Rajshahi City, Bangladesh. Brazilian 
Journal of Infectious Diseases, 12, 400-410.

https://doi.org/10.1590/s1413-86702008000400006

Nahar, Q., El Arifeen, S., Jamil, K., \& Streatfield, P. (2015). Causes of Adult Female Deaths in Bangladesh: Findings from Two National Surveys. BMC Public Health, 15, 911. https://doi.org/10.1186/s12889-015-2256-6

Nessa, K. et al. (2008). Field Evaluation of Simple Rapid Tests in the Diagnosis of Syphilis. International Journal for the Study of Aids, 19, 316-320. https://doi.org/10.1258/ijsa.2007.007280

Pisani, E. (2008). The Wisdom of Whores: Bureaucracy, Brothels and the Business of Aids. London: Granta Books.

Pruss-Ustin. A. et al. (2013). HIV Due to Female Sex Work: Regional and Global Estimates. PLoS ONE, 8, e63476. https://doi.org/10.1371/journal.pone.0063476

Qudus, A. (2015). Beyond the Myth of Puritan Bangladesh: Pre- and Extra-Marital Sexual Relations among Lower Class Urban Men. Journal of Comparative Family Studies, 46, 451-460.

Rahman, M. et al. (2000). Etiology of Sexually Transmitted Infections amongst StreetBased Female Sex Workers in Dhaka, Bangladesh. Journal of Clinical Microbiology, 38, 1244-1246.

Rashid, S. (2006). Small Power, Little Choice: Contextualising Reproductive and Sexual Rights in Slums in Bangladesh. Institute of Development Studies Bulletin, 307, 69-76. https://doi.org/10.1111/j.1759-5436.2006.tb00305.x

Rob, U., \& Mutahara, M. (2000). Pre-Marital Sex among Urban Adolescents in Bangladesh. International Quarterly of Community Health Education, 20, 103-111. https://doi.org/10.2190/NFLM-E0MY-Q26N-DBVH

Ruiz, J., Martinez, A., \& Belchi, A. (2017). Dismantling the Man-Made Myths Upholding Female Genital Mutilation. Health Care for Women International.

Safi, M. (2017). India Weighs up the Return on Cash Handouts for the Poorest. Guardian Online 6 February 2017. www.theguardian.com

Salim, N. (2004). Sex Trade Workers in Bangladesh: An Exploratory Study in Sex Workers' Movement, and Patriarchy. Halifax: Dalhousie University.

Sarkhar, K., Bal, B., Mukherjee, R. et al. (2008). Sex-Trafficking, Violence, Negotiating Skill, and HIV Infection in Brothel-Based Sex Workers of Eastern Indian, Adjoining Nepal, Bhutan, \& Bangladesh. Journal of Health, Population and Nutrition, 26, 223231.

Shahrin, L. et al. (2014). Characteristics and Predictors among Hospitalized HIV-Infected Patients in a Low HIV Prevalence Country: Bangladesh. PLOS ONE, 9, e113095. https://doi.org/10.1371/journal.pone.0113095

Shamim, I. (2010). State of Trafficking in Women and Children and Their Sexual Exploitation in Bangladesh. Dhaka: Centre for Women and Children's Studies.

Silverman, T., \& Tait, M. (2016). Dalatdia. (Film, 11 Minutes, \& 40 Seconds) www.guardian.com

Simkhada, P. and Bagley, C. (2008). Excluded and Exploited: The Sexual Trafficking of Girls and Women from Nepal to India. In C. Bagley, \& G. Verma (Eds.), Challenges for Social and Educational Inclusion: Studies from Britain and the Indian Sub-Continent (pp. 219-263). Rotterdam: Sense Educational Publishers.

Standing, G. (2011). The Precariat: The New Dangerous Class. London: Bloomsbury.

Sultana, H. (2015). Sex Worker Activism, Feminist Discourse and HIV Bangladesh. Culture, Health and Sexuality, 17, 777-788. https://doi.org/10.1080/13691058.2014.990516

SWN, \& SWASA (2016). Submission on the Status of Sex Workers in Bangladesh to the 
United Nations Committee on the Elimination of Discrimination against Women. Dhaka: Sex Workers' Network (SWN) Bangladesh and Sex Workers and Allies in South Asia (SWASA), Bangladesh Chapter.

Torry, M. (2015). 101 Reasons for a Citizen’s Income. Bristol: The Policy Press.

Uddin, S. et al. (2014). High Risk Behaviour of HIV/AIDS among Female Sex Workers in Bangladesh: Survey in Rayshahi City. Japanese Journal of Infectious Diseases, 67, 191196. https://doi.org/10.7883/yoken.67.191

UNODC (2009). Global Report on Trafficking in Persons. New York, NY: United Nations Office on Drugs and Crime. www.unodc.org

Urada, L., Goldenberg, S., Shannon, K., \& Strathdee, S. (2014). Sexuality and Sex Work. In D. Tolman (Ed.), APA Handbook of Sexuality and Psychology, Vol. 2: Contextual Approaches (pp. 37-76). Washington DC: American Psychological Association.

Vanderpitte, R., Lyerle, R., Dallabetta, G. et al. (2006). Estimates of the Number of Female Sex Workers in Different Regions of the World. Sexually Transmitted Infections, 82, 18-15.

World Bank (2015). HIV/AIDS in Bangladesh. New York, NY: The World Bank.

Zareen, A. (2014). Children in Brothels. The Daily Star (Dhaka).

Submit or recommend next manuscript to SCIRP and we will provide best service for you:

Accepting pre-submission inquiries through Email, Facebook, LinkedIn, Twitter, etc. A wide selection of journals (inclusive of 9 subjects, more than 200 journals)

Providing 24-hour high-quality service

User-friendly online submission system

Fair and swift peer-review system

Efficient typesetting and proofreading procedure

Display of the result of downloads and visits, as well as the number of cited articles

Maximum dissemination of your research work

Submit your manuscript at: http://papersubmission.scirp.org/

Or contact aasoci@scirp.org 